Originally published in International Journal of Electronic Governance, vol. 6 (4), pp. 281-301. DOI: 10.1504/IJEG.2013.060644.

\title{
Joining the online video conversation? Discourse and practices of European political institutions and politicians on YouTube
}

Patrícia Dias da Silva, Escola Superior de Comunicação Social, Instituto Politécnico de Lisboa

\begin{abstract}
To mimic the online practices of citizens has been declared an imperative to improve communication and extend participation. This article seeks to contribute to the understanding of how European discourses praising online video as a communication tool have been translated into actual practices by politicians, governments and organisations. By contrasting official documents with YouTube activity, it is argued that new opportunities for European political communication are far from being fully embraced, much akin the early years of websites. The main choice has been to use YouTube channels fundamentally for distribution and archiving, thus neglecting its social media features. The disabling of comments by many heads of state and prime ministers - and, in 2010, the European Commission - indicates such an attitude. The few attempts made to foster citizen engagement, in particular during elections, have had limited success given low participation numbers and lack of argument exchange.
\end{abstract}

Keywords: conversation; online video; YouTube; European Commission; European Union; online participation; e-democracy; EUTube; social media; public policy. 
Postprint version. Please refer to the published article for citation purposes:

Dias da Silva, Patricia (2013), "Joining the online video conversation? Discourse and practices of European political institutions and politicians on YouTube,” Int. J. of Electronic Governance, vol. 6 (4), pp. 281-301. DOI: 10.1504/IJEG.2013.060644.

\section{Introduction}

As the first decade of the twenty-first century progressed it became clear that the Internet's landscape was changing. One of the most important transformations was the passage from an almost strictly text-based Internet to the prevalence of image, and video in particular. Various "converging factors" facilitated such process: developments in the Internet backbone; the establishment of compression/ decompression standards; the increasing access to high-speed connections; the advancements in mobile phones and terminals such as smartphones, netbooks and tablets; and emerging economic models (Gervais, 2010, p.31). Particularly due to its perceived informality and absence of mediation, online video is regarded as the perfect medium to carry out conversations on political affairs, bringing politicians and citizens closer together. Moreover, as a conveyor of political discussion across boundaries, YouTube bears the promise of enabling an international public sphere and the construction of a shared identity. However, most studies of politicians and political institutions' YouTube practices are dedicated to campaigning and the national context, in specific to the reality of the USA (eg. Xenos, 2010).

By contrasting online video practices with official discourse, this article explores the case of the European Commission (EC) as an example of a political effort to employ social web tools to improve communication. The initiatives here entailed are much broader in scope than the dissemination of information; they are officially presented as seeking to promote a shared European public sphere and citizen engagement. As a result, the first section focuses on how online participation has been addressed in recent research, in particular in its discursive forms, as deliberation and conversation. It is followed by the study of key documents focusing on the representation of participation, e-democracy, citizen engagement and digital media, in order to frame and better understand the strategy behind the launching and development of the EC's YouTube channel. The third section consists of an overview of the first two years of the channel itself, focusing on the uploaded videos as well as the interactions with and between users. This analysis is complemented by a comparison with other channels of European Union (EU) institutions and European politicians in terms of the type of channel, videos and interaction practices. 
Postprint version. Please refer to the published article for citation purposes:

Dias da Silva, Patricia (2013), "Joining the online video conversation? Discourse and practices of European political institutions and politicians on YouTube,” Int. J. of Electronic Governance, vol. 6 (4), pp. 281-301. DOI: 10.1504/IJEG.2013.060644.

\section{Thinking citizen participation in Information Society}

As studies on Internet and politics have brought to light (e.g. Chadwick and Howard, 2009; Coleman and Blumler, 2009; Correia, Fidalgo, and Serra, 2003; Proulx and Jauréguiberry, 2003), the relation between the Internet and citizen participation is a complex issue, requiring reflection from multiple perspectives and disciplines. The issues regarding the loss of public trust in governments and consequently the decline in their legitimacy have a strong presence in today's media coverage, academic work and political speeches. This matter has generated vast controversy in which the current democratic model is frequently criticised, even if mainly due to the loss of faith in its processes and institutions and to the consequent onset of a "crisis of disengagement" (Coleman and Blumler, 2009, p.1).

"E-democracy" and "e-government" have gained prominence to describe a computer mediated relationship between government and citizens, including in public policies. The democratic potential of the web is associated with its capacity to allow politicians to have direct conversations with citizens and to reach the disenfranchised. The social web in particular is said to level the communicational playing field by giving citizens the means to express themselves. The main cause of anxiety in this context is linked to the widening of divides that may reinforce discriminatory conditions. Meanwhile, other sources of criticism are downplayed, especially in the official rhetoric promoting "Information Society" and "e-democracy" or exalting the potential of "Web 2.0." There are constraints to the full realization of all hopes and expectations in edemocracy and "net politics" may well result in individualisation, unequal access and disenfranchisement (Golding, 2000), the exact opposite of the prevailing political discourse.

From early on, a positive outlook was common in progress statements concerning e-government as service delivery and there were in fact significant investments in this area. Yet the promotion of e-democracy towards citizen empowerment seemed to be lacking (Dutton and Peltu, 2007). Rachel Gibson et al.

\footnotetext{
${ }^{1}$ Coleman and Blumler (2009) demonstrated how the British Government carried out a rhetorical construction of e-democracy in the UK, particularly in political speeches from the late 1990s onwards. Golding makes a similar claim regarding information society, "if the birth of the information society is inevitable, it will none the less not lack for powerful and rhetorically insistent midwives" $(2000,169)$.
} 
Postprint version. Please refer to the published article for citation purposes:

Dias da Silva, Patricia (2013), "Joining the online video conversation? Discourse and practices of European political institutions and politicians on YouTube,” Int. J. of Electronic Governance, vol. 6 (4), pp. 281-301. DOI: 10.1504/IJEG.2013.060644.

(2004) note that the first theorisations of Internet and democracy centred themselves on the former's capacity to promote direct democracy, although very few significant changes could be noticed. E-democracy has become an "umbrella concept" for distinct online practices, albeit mainly focused on how technology can enhance participatory forms of democracy (Zittel, 2004). Despite its widespread presence in official documents as well as in academic work, e-democracy is not a clear concept, sharing such weakness with many other terms employed in Internet studies.

Although praising ICT as solutions to shortcomings in contemporary democratic systems is often associated with participatory notions, in public policy the emphasis is on the enhancement of representative democracy. Largely dominating "mainstream digital democracy thinking and practice" in the USA, Oceania and Europe, the latter has been described as the "liberal-individualist position" and is allegedly the easiest option due to the pervasiveness of its rhetoric and practice (Dahlberg, 2011, p.866). Still, values and practices of deliberative democracy have become more influential in these areas of the world. The English translation of Habermas' seminal work The Structural Transformation of the Public Sphere is referenced as a key influence on the growing interest in participatory models of democracy and deliberation (Brandenburg, 2006). ${ }^{2}$ The focus on online political participation and the promotion of e-democracy has contributed to this development of research centred on models of deliberative democracy, or "discursive participation" (Carpini et al., 2004). Given their alleged "ability to foster dialogue, debate and discussion" (Correia, 2008, p.88), recent social theory has claimed the adequateness of the use of information and communication technologies to the deliberative model, also called a "pluralist democracy" (Dijk, 2012).

The overview of works on online political discussion has, however, led to the realisation that it may be necessary to overcome the deliberation model and take a closer look at contradictory tensions to fully understand online exchanges (Greffet and Wojcik, 2008). Not all online conversations are strictly oriented towards deliberation (Flichy, 2008). For over a century, conversation has indeed been considered to play a pivotal

\footnotetext{
${ }^{2}$ In the 1980s, liberal representative democracy had increasingly become the target of theoretical criticism, and calls for a more participatory alternative intensified, marking a rupture with instrumental perspectives of democracy (Vieira and Silva, 2013).
} 
Postprint version. Please refer to the published article for citation purposes:

Dias da Silva, Patricia (2013), "Joining the online video conversation? Discourse and practices of European political institutions and politicians on YouTube,” Int. J. of Electronic Governance, vol. 6 (4), pp. 281-301. DOI: 10.1504/IJEG.2013.060644.

political role, especially when it is informal (Tarde, 1989 [1901]). ${ }^{3}$ Rather than orchestrate debates and recruit citizens to participate in them, Cardon (2010) argues that institutions should join online conversation initiated by citizens, and not the reverse. This researcher highlights the unpredictability of political practices of Internet users and their resistance to "debate on command;" in fact, such initiatives only generated disappointment and low, highly motivated, mobilisation (Cardon, 2010, pp.83-4). This failure results from different models of communication being privileged: the "traditional information-producer/provider versus client model" by the government, and "dialogue" by the citizens (Bakardjieva, 2005).

Garcia points out that while studying the Internet's positive influence in opening up the discussion as to sources, voices and instruments, one must consider "problems regarding information reliability, new social limits (the digital divide) and, in particular, the transformation of the public sphere" (2011, p.758). Even international organisations with an overall positive assessment fear democracy may become more vulnerable by the careless introduction of ICTs to this domain (OECD 2003).

An increase in participation tools and mechanisms demands fostering active citizenship and digital literacy. It also requires that government officials or civil servants master the technologies being used by citizens and improve communication skills related to clearness in the presentation of discussion topics and the successful moderation of online discussions (see Wojcik, 2007). In addition, how governments deal with the contribution of citizens is not a mere logistical and technical problem; it implies a change in mentality towards the acceptance of regular contributions from the citizenry, and the resulting willingness to model policies accordingly.

Fuchs observes that the ability to voice one's opinion online does not mean elite groups will not remain the actual decision-makers and thus " $[\mathrm{t}]$ he information produced then constitutes an endless flood of data, but not significant political voices" (2009, p.83). In 2008, the United Nations' (UN) annual assessment of e-Participation trends noted that "only 11 per cent of countries surveyed committed themselves to incorporating the results of e-participation into the decision-making process. This figure

\footnotetext{
${ }^{3}$ For Tarde, private conversations and discussions politically trump the conversations and discussions held in Parliament, "the cafés, the salons, the shops, any place where one talks, are the true factories of power" (1989 [1901], 65).
} 
Postprint version. Please refer to the published article for citation purposes:

Dias da Silva, Patricia (2013), "Joining the online video conversation? Discourse and practices of European political institutions and politicians on YouTube,” Int. J. of Electronic Governance, vol. 6 (4), pp. 281-301.

DOI: 10.1504/IJEG.2013.060644.

clearly indicates that the majority of governments are not in a position to directly involve citizens into the decision-making process" (UN, 2008, p.65). If the motives for engaging citizens are merely populist or a way to avoid making hard decisions, and if policies do not reflect the contributions of citizens, then there is no improvement in government-citizen relations. Genuine political will towards participatory politics is required for trust to be built and for engagement initiatives to be positive for democracy.

\section{Policies for Communicating Europe in the 21st Century}

Following the failed approval of the European Constitution in 2005, the need to foster a sense of a European identity - a European "imagined community" - grew stronger. In Benedict Anderson's work the novel and the newspaper "provided the technical means for 're-presenting'" the community to the nation (1991 [1983], p.25). Discussing the conservative objection to European integration based on the fact that "a European people does not exist," Habermas (2009) states that nation-states do not have the prerogative of being able to foster political identity and solidarity. Nevertheless, "the development of a European-wide political public sphere - that is, of a communicative network extending across national boundaries and specializing in relevant questions - is of central importance for the emergence of such a European identity," even if it should be a weaker form of identity (2009, p.87). In his view, a European public sphere is equally pivotal for enabling citizens to monitor the complexity of European institutions and respective decision-making processes. Their lack of intelligibility, as well as the citizens' inability to have a direct interference in them, is commonly perceived as the "democratic deficit" of the EU. Although institutional changes have been made to enhance the role of citizens and improve transparency in processes, this perception has not waned due to its cultural roots (Swaan, 2007) and an accompanying “communication deficit" (Schlesinger, 2007).

In this century, the Internet became the medium of choice to establish political identity on a wider scale, namely in the process of preparing one more step towards European integration. A major issue was the online prevalence of Euroscepticism, as was verified, for example, in the analysis of French websites on the referendum for establishing a European Constitutional Treaty (Fouetillou, 2008). From the link to 
Postprint version. Please refer to the published article for citation purposes:

Dias da Silva, Patrícia (2013), "Joining the online video conversation? Discourse and practices of European political institutions and politicians on YouTube," Int. J. of Electronic Governance, vol. 6 (4), pp. 281-301. DOI: 10.1504/IJEG.2013.060644.

stronger models of democracy, reminding us of conceptions of "participatory democracy" (Barber, 1984), Internet policies have also turned to "participatory culture" (Jenkins, 2006), as user-generated content is the focus of increasing attention. This position can be found in OECD publications $(2003,2007)$ and in the above mentioned UN assessments, as well as in the EU documents discussed below. Nevertheless, the relation between a transnational institution like the EU and digital media faces several challenges, namely preconceptions, different philosophies and rules, as well as bureaucratic hurdles.

The European Commission (EC) is an institution invested with technical competencies, therefore responsible for studies, proposals, and progress assessment in key policy areas. To understand the changes in how participation is construed and is accordingly promoted in its online version, leading up to a focus on online video, I will pay special attention to two policy areas - Information Society and Communication during the period prior to the launch of EUTube as well as its first appraisals. Taking into consideration the contributions of critical discourse analysis, both the documents' content and form are considered (Fairclough, 1995), particularly through a lexical analysis (including the identification of predominant terms and their connotations as well as lexical absence), and careful attention to the presence of rhetoric tropes such as the metaphor (Machin and Mayr, 2012).

Marking the transformation of Information Society into a policy focal point, in 1999 the eEurope initiative was launched "to ensure the European Union fully benefits for generations to come from the changes the Information Society is bringing" (COM [1999] 687, p.2), comparing them to those induced by the Industrial Revolution. It described the former as affecting "everyone, everywhere" (COM [1999] 687, p.2) and not restricted to technological aspects. There is a strong feeling of both urgency and imperativeness in the text, emphasised by a vivid description of transformations underway and of the timing. Such sentiments are also demonstrated in the statement of its overall objective, self-characterised as ambitious: "to bring everyone in Europe every citizen, every school, every company - online as quickly as possible" (COM [1999] 687, p.5). Despite the description of a wide reach, the economic aspect is a major influence in the increasing attention directed to the topic of Information Society, in an 
Postprint version. Please refer to the published article for citation purposes:

Dias da Silva, Patricia (2013), "Joining the online video conversation? Discourse and practices of European political institutions and politicians on YouTube,” Int. J. of Electronic Governance, vol. 6 (4), pp. 281-301. DOI: 10.1504/IJEG.2013.060644.

attempt to follow USA's growth in the 1990s. The emphasis on the key role of ICT in fostering economic growth, productivity, and competitiveness is present throughout all the texts analysed, which is consistent with critical sociological analyses of Information Society (e.g. Mattelart, 2003; Proulx, 2008).

On the specific issue of government-citizen relations, eEurope includes an action on "government online" in its first communication in 1999. A connection is established between the quality of public information, the relevance of the Internet to everyday life, inclusion and its resulting benefits. One of them is to bring governments closer to citizens: the goal is "to go beyond simply publishing legislation and white papers on the web and establish a discussion and feedback forum possibly with independent moderators" (COM [1999] 687, p.16). However, this intent is not reflected in the measures outlined in the action plans that followed, namely eEurope 2002 (CEC and CEU, 2000) and eEurope 2005 (COM [2002] 263). The 1999 document very clearly conceives "participation" as "taking part of" or "sharing in." "In the three documents, participation means enjoying the economic benefits of information society and the opposite of exclusion, instead of connoting citizen engagement. The promotion of participation is hence integrated in e-inclusion strategies, which is arguably the more social side of these economically focused action plans.

In Challenges for the European Information Society beyond 2005 the issue of government-citizen relations, besides strictly administrative procedures, starts to gain importance and becomes the subject of wider discussion: "the use of ICT in this area [public services] aims at improving the quality of the services provided, and at increasing democracy and transparency" (COM [2004] 757, p.7). Also as part of the preparatory work for the strategy to be adopted on Information Society "beyond 2005," a public consultation was launched. Despite this issue being downplayed in the eEurope action plans, the engagement of citizens is among the political challenges identified by contributors in this consultation process: "the use of ICT is going to enable citizenoriented decision-making processes, and therefore, serving to citizen empowerment" (EC, 2005, p.6).

\footnotetext{
${ }^{4}$ As for example in the action "eParticipation for the disabled": "accessible technologies which address their specific needs enable their participation in social and working life on an equal basis" (COM [1999] $687,13)$.
} 
Postprint version. Please refer to the published article for citation purposes:

Dias da Silva, Patricia (2013), "Joining the online video conversation? Discourse and practices of European political institutions and politicians on YouTube," Int. J. of Electronic Governance, vol. 6 (4), pp. 281-301. DOI: 10.1504/IJEG.2013.060644.

The new strategic framework is officially proposed in i2010 - A European Information Society for growth and employment (COM [2005] 229). Besides the modification of the designation, abandoning "eEurope," this initiative no longer has the format of an action plan. Having a broader scope, it is understood as a "strategic framework," "laying out broad policy orientations" (COM [2005] 229, p.3), distancing itself from a piecemeal approach. In her presentation of this framework, Viviane Reding, European Commissioner for Information Society and Media (2004-2010), declared that its goal was "to build on this opportune wave of technological and economic development" (Reding, 2005, p.2). As its predecessors, i2010 is indeed mainly dedicated to economic issues, despite the presence of a societal agenda. While the term "participation" is still used in this document as a synonym of inclusion, egovernment moves from being an item on a list to an action plan in its own right.

The term "e-democracy" only appears in the e-government Action Plan (COM [2006] 173) and no reference is made in previous policy orientations (eEurope 2002, eEurope2005 and i2010), despite being the focus of prior attention in other areas of work of the Commission. Following the Ministerial eGovernment Conference $2003^{5}$ and the eGovernment Communication (2003), a seminar was held in 2004 by the eGovernment Unit (Information Society Directorate General, EC) to review experiments carried out in this field. Its report reflected on the subject of e-democracy in general, focusing then in developments in eVoting and eParticipation. In addition, the issue of participation in terms of active citizen engagement has long been integrated in the discussions on governance, for instance, in White Paper on European Governance (COM [2001] 428).

Despite the past mismatch in governance and ICT policy areas, in the field of EU communication resorting to ICT for the promotion of citizen engagement soon became common in policies and frameworks. A clear signal is the involvement of the Directorate General for Communication (DG COMM) - under the responsibility of Margot Wallström, also Vice-President of the EC (2004-2010) - in fostering the use of the Internet to bring European citizens, EU institutions and EU officials closer together.

\footnotetext{
${ }^{5}$ This event was the second of a series of Ministerial eGovernment Conferences, which had begun in 2001 , in connection with the eEurope initiative.
} 
Postprint version. Please refer to the published article for citation purposes:

Dias da Silva, Patricia (2013), "Joining the online video conversation? Discourse and practices of European political institutions and politicians on YouTube,” Int. J. of Electronic Governance, vol. 6 (4), pp. 281-301.

DOI: 10.1504/IJEG.2013.060644.

In the Action Plan to Improve Communicating Europe by the Commission (SEC [2005] 985), the Internet is seen as an important medium of communication and the EU website is highly praised, even if recognising margin for improvement. Launched in 1995 in Brussels, at a G7 ministerial meeting on information society, EUROPA integrated the Commission's first initiatives associated with the Internet. In 2001 this website underwent a process of improvement defined in the EUROPA II communication; eEurope action plans and the fulfilment of their 'government online' objective are linked to it.

According to the White Paper on a European Communication Policy, the existing communication strategy was lagging behind the transformations affecting the $\mathrm{EU}$, and the distance from citizens was growing. The 'sense of alienation' invoked in this White Paper is attributed to "the inadequate development of a 'European public sphere" for discussion on the EU, the lack of voice felt by citizens as well as the nonexistence of an "obvious forum" for these debates to take place (COM [2006] 35, 4-5). In 2007, the document Communicating Europe in Partnership built on such findings. It advocated the needed development of said European public sphere by proposing the creation of "cross-border communication channels promoting debate and dialogue on issues of common concern while reflecting the European agenda" (COM [2007] 568, p.9). A "cross-media publishing policy" was suggested, while new technologies assumed an important position in communication policies. In this respect, two courses of action were indicated: transformations to the EUROPA website; and outside this website, aiming to become "more involved in interviews and participation in discussions in other sites" (COM [2007] 568, p.12).

Communicating about Europe via the Internet. Engaging the citizens, released at the end of 2007, defined these initiatives as well as the framework for a new Internet strategy, stating that the Commission should "embrace the Internet culture and online communication opportunities" (SEC [2007] 1742, p.3). As a result, the European Commission, through DG COMM, decided it was also important to follow the citizens to where the discussion was supposedly taking place. And this meant going to the popular video website YouTube.

As previously with websites (Cunha and Voerman, 2008), European politicians, 
Postprint version. Please refer to the published article for citation purposes:

Dias da Silva, Patricia (2013), "Joining the online video conversation? Discourse and practices of European political institutions and politicians on YouTube,” Int. J. of Electronic Governance, vol. 6 (4), pp. 281-301.

DOI: 10.1504/IJEG.2013.060644.

governments, and institutions did indeed realise that creating a YouTube channel had its benefits as a direct way to publish information, a tool for interaction, or simply because it is good public relations. But in both cases early efforts were half-hearted. When government websites first went online, almost all were upgraded versions of the institutional brochure; correspondingly, in personal websites of members of parliament the new opportunities for communication were not being fully embraced (Zittel, 2004). Similarly, by the end of the first decade of 2000 , politicians and governments' channels often resembled an archive for television-made material, using YouTube mainly for broadcasting purposes.

Participation as a concept has gained more importance in public policies concerning Information Society, while changing its own definition: from inclusion being able to share the benefits of a connected society - to political engagement - the ability to discuss and influence political decisions. At the same time, to follow the citizens and mimic their online practices are declared as imperatives in order to improve communication and to extend participation. The Internet and the social web are perceived by the EU as useful resources that should - or even have to - be employed in citizen engagement, although they are not regarded as a panacea for improving participation (a term present in EU documents). EU communications are careful to distance the view of this organisation from visions of extreme "directism" present in early technology utopias, but still noticeable in some perspectives. The praise of participation is made with restraint, since the majority of governmental measures for citizen engagement aim to strengthen representative democracy, and not replace its political and institutional mechanisms. In this perspective, even if augmented, citizen participation is seen as solely complementary to parliamentary decision-making. This point of departure may help explain the limitations of online dialogue between citizens and representatives.

\section{Communicating Europe on YouTube}

Politics on YouTube has undergone changes, and one of these transformations resulted from the inclusion of online video in government-citizen communication strategies. YouTube's democratic advantages were attributed to shortening the distance 
Postprint version. Please refer to the published article for citation purposes:

Dias da Silva, Patricia (2013), "Joining the online video conversation? Discourse and practices of European political institutions and politicians on YouTube," Int. J. of Electronic Governance, vol. 6 (4), pp. 281-301.

DOI: 10.1504/IJEG.2013.060644.

from citizens, and ranged from providing direct information to enabling interaction. All this while joining citizens where they already were - much like Cardon proposed in his work - instead of trying to draw them to official websites. To improve the understanding of how official discourse turns into concrete action, it became important to go beyond the analysis of EU documents and study the resulting YouTube practices. The goal was to experience such practices from the point of view of a citizen, meaning it implied having as sole source publicly available information, rather than carrying out interviews or applying questionnaires.

Figure 1: The EUTube channel. Screenshot taken on 11-08-2011.

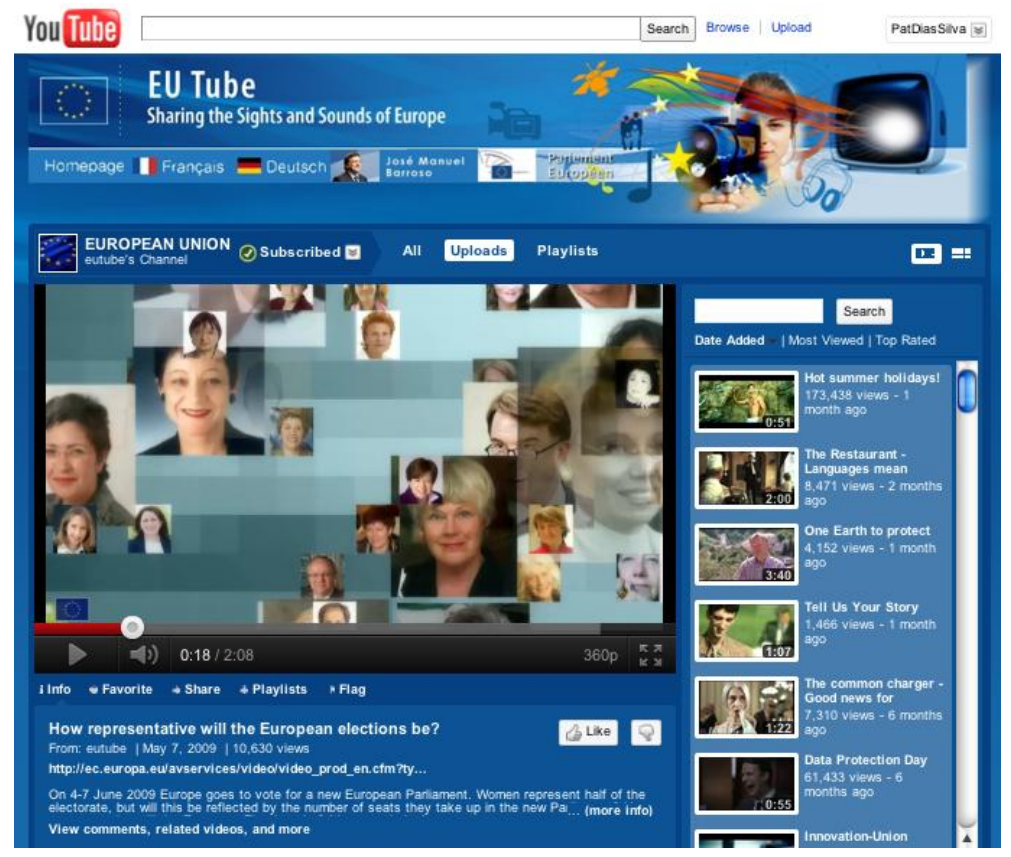

Source: YouTube

This study of the first two years of the EUTube channel (see Figure 1) was focused on the rhetorical organization of discourse (visual images and verbal texts), identifying key themes, persuasion techniques, complexities and contradictions, aided by a compositional approach (Rose, 2002). The compositional methodology focuses primarily on the site of the image, looking at content, and in the case of moving images, as inspired by the work of James Monaco (2000), the spatial organization, the temporal organisation, and sound. Such analysis was complemented by considerations on the site of production, regarding the source of material and technologies involved. Finally, the site of audiencing was studied in respect to the social practices of spectating (Rose, 
Postprint version. Please refer to the published article for citation purposes:

Dias da Silva, Patricia (2013), "Joining the online video conversation? Discourse and practices of European political institutions and politicians on YouTube,” Int. J. of Electronic Governance, vol. 6 (4), pp. 281-301.

DOI: 10.1504/IJEG.2013.060644.

2002). The same methodological approach was used to study the other European channels. Understanding the shortcoming of an analysis strictly centred in the image itself, I resorted to methodological tools from ethnographic approaches to studying the Internet (Hine 2000), and recent online case studies (Millerand et al., 2010). Important lessons were learned from the pioneer studies carried out by YouTube ethnographers (Lange, 2007a, 2007b; Strangelove, 2010; Wesch, 2008). To give context to videos under review, establishing narrative threads and reconstructing public dialogue (Warburton, 1998), I examined other videos, websites, online pages of news media and blogs, adding to the perception of audiencing practices.

In October 2007, Commissioner Margot Wallström applauded the success of the English version of the EUTube channel, launched on June 29, 2007 (EC, 2007). According to this EC press release, it had "received over one million hits on its homepage and almost seven million video views since its launch." The praise continued in official documents: "The recent creation of the dedicated EUTube channel on YouTube has been a first, and successful, step in giving the Commission a higher profile in the Internet environment. EUTube has successfully reached out to a new audience and stimulated lively debate on the EU and the Commission's policies and activities" (SEC [2007] 1742, p.12).

Figure 2: Video uploading trend on EUTube, from June 2007 to June 2009 (mean value line is indicated).

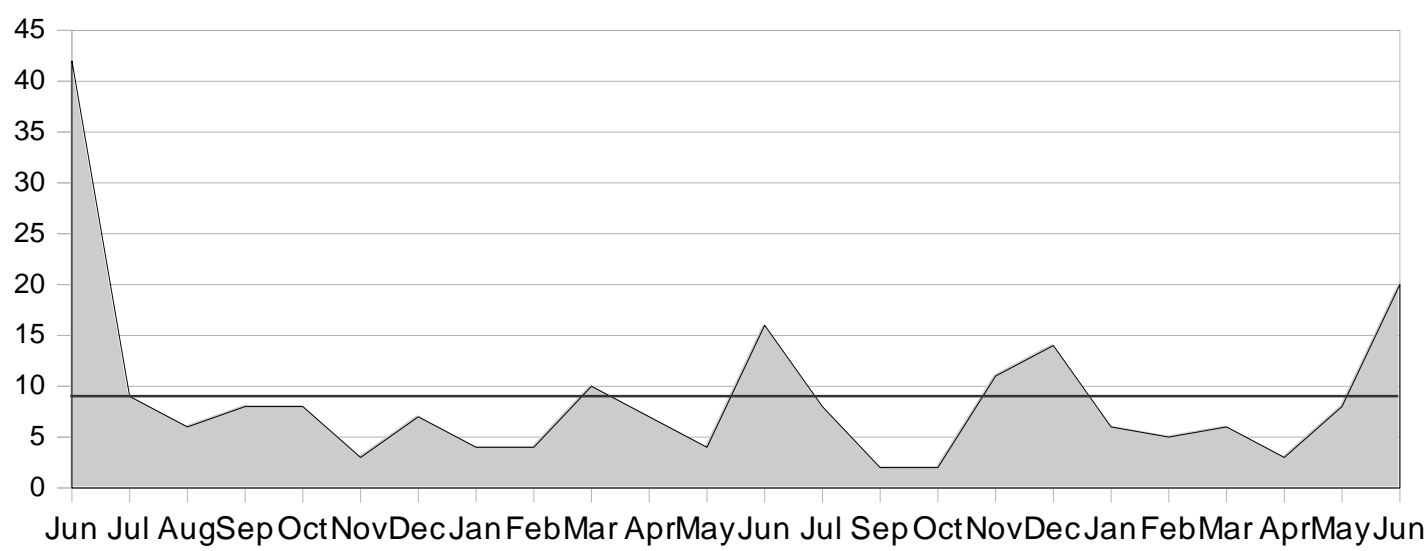

Source: YouTube 
Postprint version. Please refer to the published article for citation purposes:

Dias da Silva, Patricia (2013), "Joining the online video conversation? Discourse and practices of European political institutions and politicians on YouTube,” Int. J. of Electronic Governance, vol. 6 (4), pp. 281-301.

DOI: 10.1504/IJEG.2013.060644.

A considerable number of videos were uploaded before the channel was launched. The surges in uploading trends in the first two years present in Figure 2 correspond to four different periods, namely the one-year anniversary (featuring a retrospective of videos), the end of 2008 (even if on different issues, ten videos were uploaded on the same day), and a special series of 16 videos on climate change: "YOU control climate change." The last peak coincided with the two-year anniversary, but this time there was no direct reference to the date. Videos were sometimes uploaded in groups according to their theme and/or area of EC intervention. Besides the set on climate change just mentioned, there is a series dedicated to alterations in roaming regulation (all uploaded on June 14, 2007), and a "Travelling in Europe" series (all uploaded on November 27, 2008), to name a couple of examples.

Figure 3: Tag cloud of the videos uploaded on EUTube between June 2007 and June 2009, font size indicates frequency (generated on http://www.wordle.net).

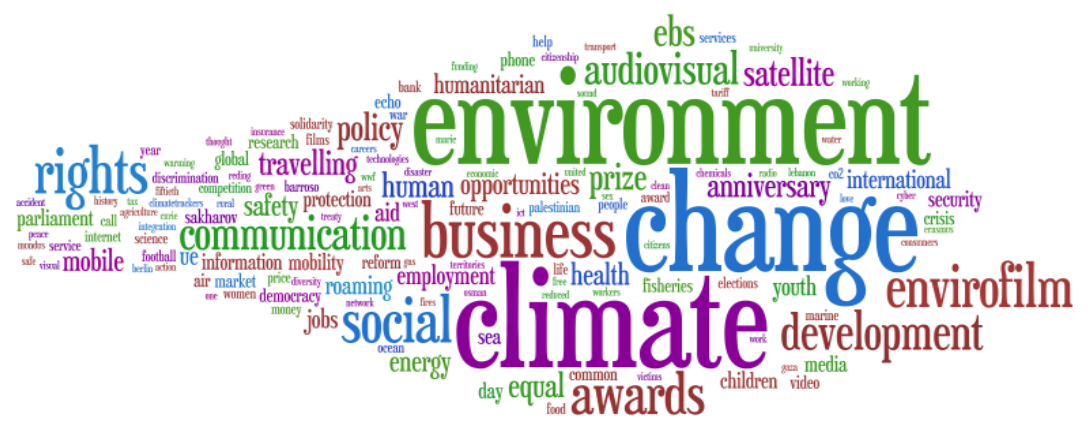

Source: YouTube

Studying all the videos uploaded between June 2007 and June 2009, and removing self-referring tags (e.g. eutube, europe), it becomes clear that there is a strong focus on environmental issues and climate change (frequency: climate -37 ; change 36; environment: 36), subjects that can be considered more than strictly European and that are less controversial in this region of the world. This emphasis becomes more apparent when a tag cloud based on frequency is created (see Figure 3). ${ }^{6}$ In 2009, this topic had a strong presence in multiple agendas, since the United Nations Climate Change Conference would be taking place in Copenhagen the following December.

In 2013, tags are no longer visible for the viewer, although they are still added when videos are uploaded. 
Postprint version. Please refer to the published article for citation purposes:

Dias da Silva, Patricia (2013), "Joining the online video conversation? Discourse and practices of European political institutions and politicians on YouTube," Int. J. of Electronic Governance, vol. 6 (4), pp. 281-301.

DOI: 10.1504/IJEG.2013.060644.

Margot Wallström was directly involved in an initiative - the "Road to Copenhagen" aiming to foster citizen participation in preparatory works, both online and offline, which had been launched on November 2007. Her background as the former Environment Commissioner (1999-2004) is noted in the initiative's website and may help explain why the presence of such issues was so strong on EUTube (under the DG COMM).

All of the early videos uploaded to the EC's channel were existing work and in the following two years it was not very clear which material was purposely made for EUTube. Most of the content followed the format of corporate videos, looking very similar to promotional messages. These videos seemed to confirm studies that claimed government-funded YouTube videos were "substitutes for numerically coded instructional booklets that were traditionally produced in print formats by official agencies" (Losh, 2008, p.112). Still, some videos resembled reports from the ground, giving a more "hands on" kind of feel, featuring technicians on the field, multiple languages, without music in the background or a title sequence. Throughout the first two years of videos, the EC had to make some adjustments to the posted videos, which reflected on their overall style and length. As a result, there was an increase in the number of short clips, television ads and other videos which followed such format. In addition, videos became more humorous and animation was used more often. The latter had the advantage of overcoming language barriers, replacing speech by the universal language of cartoons.

The series "YOU control climate change," for instance, included 16 animations nearly all uploaded on June 6, 2009. ${ }^{7}$ These YouTube videos were part of a set featured on the website for the EC's awareness campaign "You Control Climate Change!," which had been launched in May 2006 by EC President José Manuel Barroso and Environment Commissioner Stavros Dimas. Framing the production of the video clips, in April that year the White Paper Adapting to Climate Change was published, and later in June 2326 the EC's Green Week conference: act and adapt was held.

\footnotetext{
7 On the website, two other animated videos uploaded to EUTube appeared on the first page:

"Everyone can save the planet" (June 21, 2007) and "Energy. Let's Save It!" (November 11, 2008). There was also a previous video called "You control climate change" uploaded two years before, in June 2007.
} 
Postprint version. Please refer to the published article for citation purposes:

Dias da Silva, Patricia (2013), "Joining the online video conversation? Discourse and practices of European political institutions and politicians on YouTube,” Int. J. of Electronic Governance, vol. 6 (4), pp. 281-301. DOI: 10.1504/IJEG.2013.060644.

Figure 4: "YOU control climate change!" series, video featuring the English teenager. Screenshot taken on 15-04-2011.

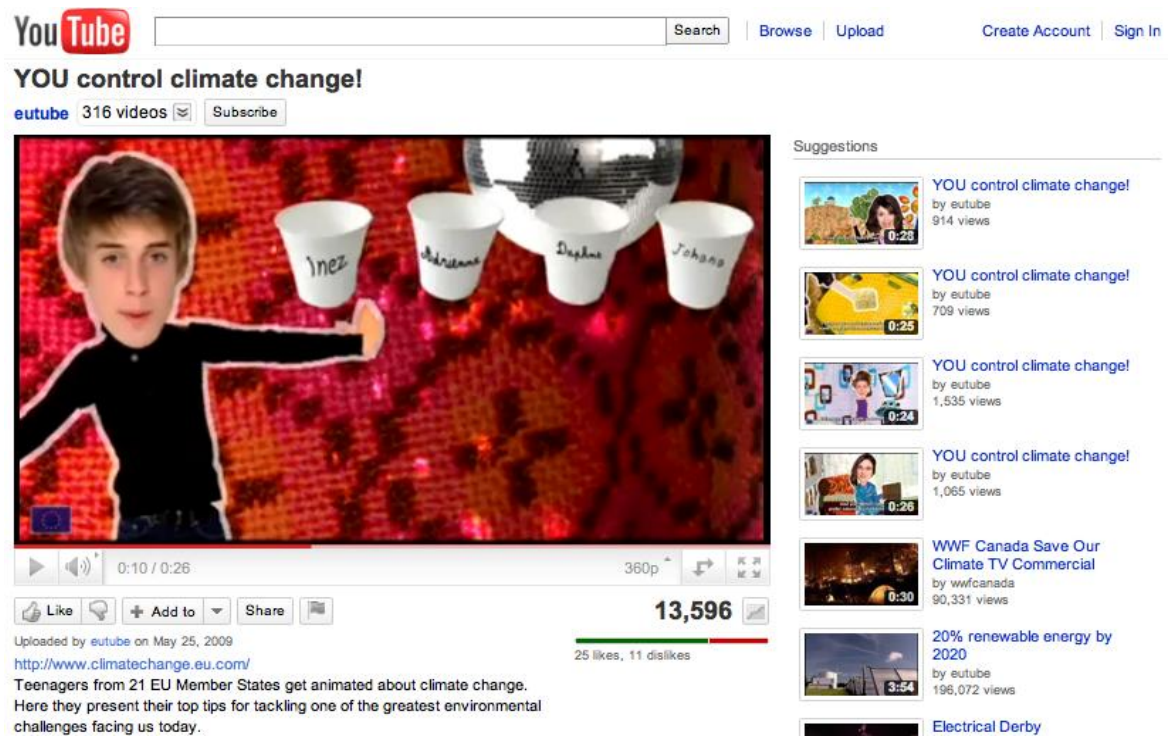

Source: YouTube

The description of each video reads "Teenagers from 21 EU Member States get animated about climate change," the same sentence presenting the videos on the EC's website dedicated to the issue of climate change. These videos - described by the DG Environment as "funny, fresh and dynamic" (DG Environment 2009) - drew their humour mostly from the quirkiness of real heads attached to cut out bodies, and the mixture of real life objects, patterned fabrics, and animated drawings (e.g. Figure 4). The comments of the two most seen and commented videos were mainly a dispute between viewers who argued "Global warming is a scam," and accused the EU of backing such ploy, and those who expressed their concern regarding this environmental issue and supported actions to prevent it. ${ }^{8}$

8 Even the most seen and commented video presented low figures: the video featuring the English teenager had only received 27 comments and under 13500 views in the six months after being posted. The other videos either had very few comments, or none at all. 
Postprint version. Please refer to the published article for citation purposes:

Dias da Silva, Patricia (2013), "Joining the online video conversation? Discourse and practices of European political institutions and politicians on YouTube," Int. J. of Electronic Governance, vol. 6 (4), pp. 281-301. DOI: 10.1504/IJEG.2013.060644.

Figure 5: The European Parliament's channel. Screenshot taken on 3-03-2011.

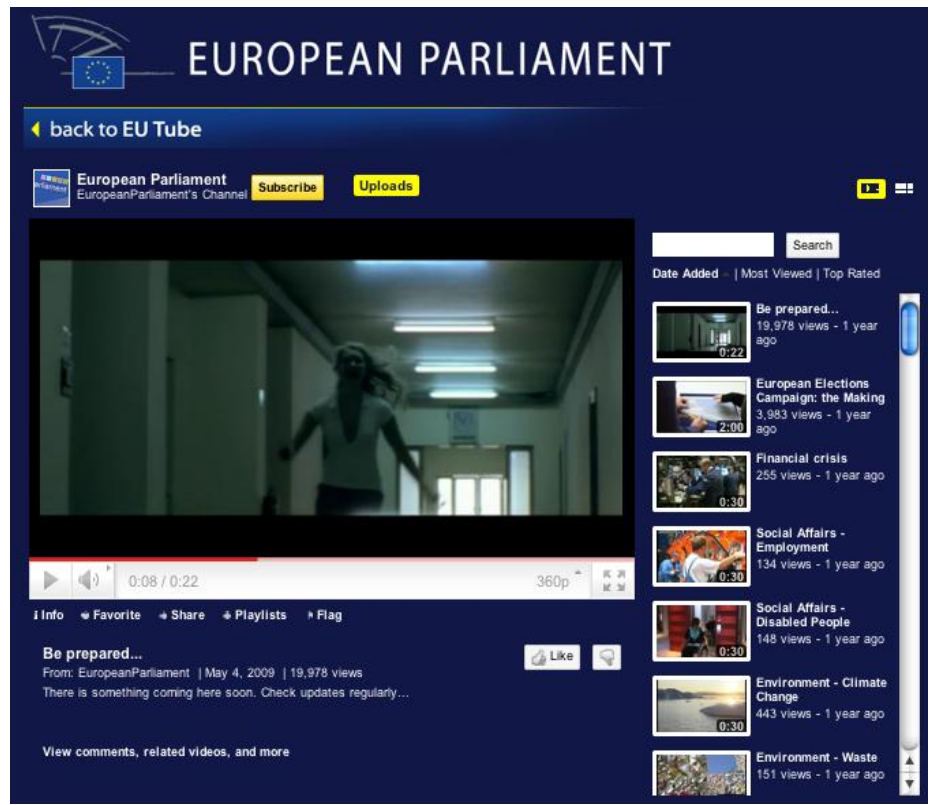

Source: YouTube

Comparing it to other channels created by EU institutions, EUTube's early months were different from the European Parliament's arrival at YouTube (Figure 5). The latter was created close to the 2009 elections and its first three videos aimed to promote voting. The strategy was to resort to parody and to adopt viral marketing techniques, an approach considered useful in increasing the reach of organisational messages (Ward and Gibson, 2009). Although both European institutions (DG Communication 2009) and external reports (Gagatek, 2010) proclaimed these videos were well received on the Internet and in other media, the publicised half a million figure corresponded to the joint views of the three videos, of which the horror movie parody (the first posted) was responsible for over half of them. Slightly over 300000 views is still far from the OECD's description of viral: "being viewed by more than one million persons in a relatively short time” (OECD, 2007, p.24). In these campaign videos the designation "viral" thus seems to reflect a performative intent, rather than being descriptive. 
Postprint version. Please refer to the published article for citation purposes:

Dias da Silva, Patricia (2013), "Joining the online video conversation? Discourse and practices of European political institutions and politicians on YouTube," Int. J. of Electronic Governance, vol. 6 (4), pp. 281-301. DOI: 10.1504/IJEG.2013.060644.

\section{Discussing Europe on YouTube}

When directly prompted to post videos, EU citizens have not responded in large numbers; there are very few video responses to the videos uploaded to EUTube, and the "lively debate" praised by the EC is restricted to comments. The most commented video on EUTube during the first two years, "Film lovers will love this" (Figure 6), which also accounted for the millions of views announced in October 2007 (EC, 2007), owed its statistics to a negative response. ${ }^{9}$ Due to featuring sex scenes considered explicit, it was eventually flagged and has since become age-restricted. From Polish catholic families, to Euroceptic British Tories, many voices made known their discontent about this video (Smith, 2007). Even if controversial videos like this one or the more recent "Science: It's a girl thing!” (June 2012) - which received so many complaints the EC eventually decided to take it down - gained visibility due to heavy criticism, European officials still praise these videos, describing them as successful for generating audience and commentary (Sachdev, 2012).

Figure 6: Flagged warning for "Film lovers will love this." Screenshot taken on 11-04-2011.
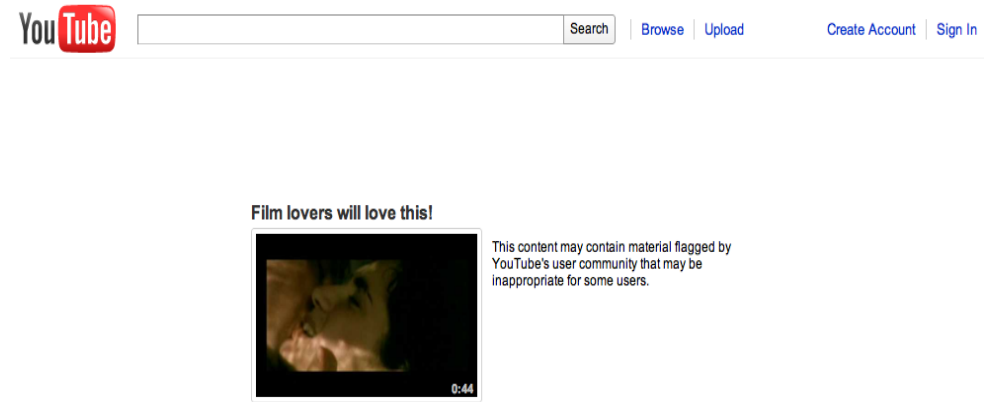

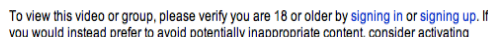

you would instead prefert to
YouTube's Safety Mode.

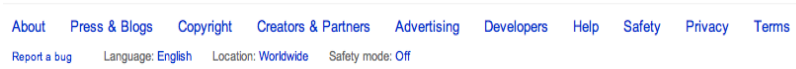

Source: YouTube

\footnotetext{
${ }^{9}$ In March 2013 this video was still the "Most popular" on the EUTube channel with close to 9 times more views than the second and over 16 times more comments than the second video - "Romanticism still alive in Europe's films" - from the same series on the MEDIA program.
} 
Postprint version. Please refer to the published article for citation purposes:

Dias da Silva, Patricia (2013), "Joining the online video conversation? Discourse and practices of European political institutions and politicians on YouTube,” Int. J. of Electronic Governance, vol. 6 (4), pp. 281-301. DOI: 10.1504/IJEG.2013.060644.

Lack of participation is not restricted to European Union institutions or even EU member states. In 2009, Norwegian Prime Minister Jens Stoltenberg launched a contest calling for video responses which received but five contributions. Perhaps such reluctance to participate is due to a perception that this is but a simulation of a dialogue, since in an actual conversation the politician cannot summarise or pick between the citizens' questions, and there are interruptions or interferences with his/her discourse. Therefore, despite being an invitation for participation, because the management of the process is entirely in the hands of the politician or political institution, their image "remains dialogical [dialogique] without being dialoguing [dialogale]. Dialogical because it integrates the other in his/her own discourse. But not dialoguing, since there is no actual exchange" (original emphasis, Yanoshevsky, 2009, p.63).

Furthermore, flaming and trolling have had some measure of success in hampering discussion on the EUTube channel, in particular for new arrivals. In a comment to a post by Margot Walström (2009) where she discussed EUTube, a user complained about this very situation:

My personal experience with EUTube's message board is that attracts the lowest type of person with little civility. I have been insulted and slandered and called the most vile names on that board. The level of intelligence is low- and closing the board would improve the decor of EUTube.

Nevertheless, another user argued that it might be a wrongful perception:

[addressing the first user], there are some nice people on EUTube. But to a certain extent, I would have to agree with you re the language used. However, many of them have been there for a long time, and a lot of the "insults" are actual bantering between themselves. I must admit, sometimes newcomers - from what I have seen - have been heavy handedly "commented" on.

Despite their policy against hate speech, to control commentary is difficult for the EC. The moderator seldom interferes, and choosing not to publish certain comments would lead to accusations of censorship, which already happens. Changes in the Barroso Commission in 2010 seemed to affect its attitude towards comments on YouTube. The comment box on the front page was permanently removed, and some of the videos posted in the first months of office had their comments disabled, including videos promoting citizen participation. Not allowing comments on videos is a common practice on YouTube by politicians and political organisations: such is the case of the 
Postprint version. Please refer to the published article for citation purposes:

Dias da Silva, Patricia (2013), "Joining the online video conversation? Discourse and practices of European political institutions and politicians on YouTube,” Int. J. of Electronic Governance, vol. 6 (4), pp. 281-301. DOI: 10.1504/IJEG.2013.060644.

President of the EC, the European Parliament, but also of national leaders of government, even during campaigns (see Figure 7). In this sense, the study of YouTube practices mirrors previous research on politicians' blogs: actual interaction falls short of declared "normative ideals of conversation" (Coleman and Moss, 2008).

Figure 7: Examples of videos with disabled comments. From left to right, top to bottom: "Mads Mikkelsen - Let your voice be heard!" (EUTube), "Discurs [sic] sur l'adoption des modifications du Traite" (Barroso), "World AIDS Day 2010" (Number10Gov) and "Sarko Ho Ho" (NicolasSarkozy). Screenshots taken on 2-03-2011.

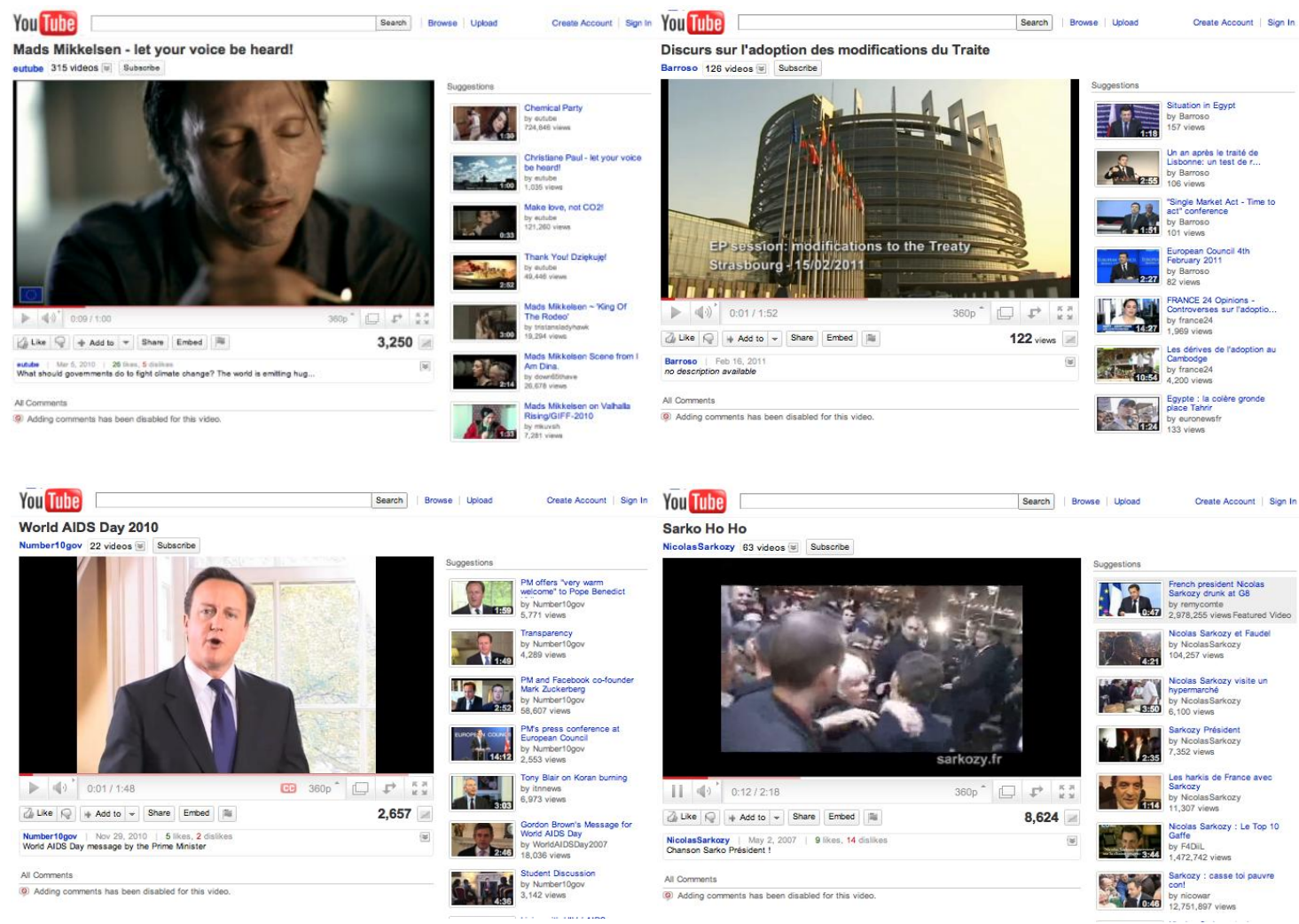

Source: YouTube

Before YouTubers, bloggers had already been faced with trolling, flaming and spam, and some chose to disable comments, while others controlled publication. However, comment management options have consequences, namely the reduction of "the overall potential volume of the commentsphere" (Mishne and Glance, 2006). Since YouTube's first years, YouTubers have been suspicious as to resorting to "corrective mechanisms," due to their implications both to freedom of speech and to the access to meaningful criticism (Lange, 2007a). In addition, moderating or banning comments is regarded as "counter to the ethos of openness that supposedly distinguishes 
Postprint version. Please refer to the published article for citation purposes:

Dias da Silva, Patricia (2013), "Joining the online video conversation? Discourse and practices of European political institutions and politicians on YouTube,” Int. J. of Electronic Governance, vol. 6 (4), pp. 281-301. DOI: 10.1504/IJEG.2013.060644.

participatory culture" (Burgess and Green, 2009, p.96). Similar government decisions to disable comments have been perceived as hindering democratic discussion, and what could have been "a clever move of bringing its message to the people," turned into a strong negative response, causing reactions such as "disbelief in the message, labels of propaganda, and unpacking of supposed truth claims of the videos" (Hess, 2009, p.414). ${ }^{10}$

Political presence on YouTube has not lived up to the potential described in official reports. A great deal of online video content is repurposed from television-made material. In many cases, channels are little more than a collection of public appearances: this is very clear in the case of the Portuguese Presidency or the British Royal House. Even if President Cavaco Silva first addressed online viewers directly when the channel was launched, and everyone was able to follow the preparations of a royal wedding in detail, we are still far from widespread appropriation of YouTube genres or engagement in conversation.

The channel for Spain's PSOE brought together videos on current events of PSOE and the socialist Government, featuring many of former Prime Minister Zapatero's speeches. Norway's Arbeiderpartiet adopts the same practice of mixing together different institutional roles: the party, the government and the person of the Prime Minister. Their more creative videos were made during the 2009 campaign period and posted on the same channel: besides the call for video already mentioned, there were experiments in story-telling and attempts at connecting social web sites by, for instance, asking on their YouTube channel for citizens to post questions on Twitter. After the campaign, the pattern of speeches and public appearances became more common. In turn, the channel on YouTube connected to Nicolas Sarkozy stopped being active after the 2007 campaign, and it was not replaced by a channel for the French Presidency during his mandate. This description of the aftermath of elections reflects a trend identified regarding the 2008 US election cycle (May, 2010).

\footnotetext{
${ }^{10}$ The case discussed in that study involved the US Office for National Drug Control Policy. As to the examples discussed in this article, since the decision to disable comments was made after my period of analysis of EUTube videos, I was not able to witness what happened in real time. A search on Google did not retrieve any reactions to this decision; in fact, the only reference to EUTube and disabling comments was a petition from 2007 at http://eutubelibre.wikidot.com/. This may lead us to conclude that disabling comments had already been attempted.
} 
Postprint version. Please refer to the published article for citation purposes:

Dias da Silva, Patricia (2013), "Joining the online video conversation? Discourse and practices of European political institutions and politicians on YouTube,” Int. J. of Electronic Governance, vol. 6 (4), pp. 281-301. DOI: 10.1504/IJEG.2013.060644.

\section{Promise and problems of online video}

Akhil Gupta (1992) argued that a transnational organization like the European Commission had difficulties in cultivating an "imagined community" because, unlike nations, it did not have the media reach for its representation. In the twenty-first century this panorama has changed, with the advent of "new European audio-visual spaces" (Eriksen, 2007). Nevertheless, it is clear that a website like YouTube poses a communication challenge for European institutions and politicians: they are still trying to understand how to deal with digital media. The main - and easiest - choice has been to treat YouTube as both a distribution channel and an archive, largely neglecting the social web features enabled by the website and undertaking little change to institutional culture.

Upon empirical analysis, one verifies there are still barriers to online discussion fostered by institutions: first, participation numbers are low; second, those who do participate seem to stand in opposite sides of the debate, pushing further away YouTubers with moderate convictions. The findings reveal that the noise and disruption produced by flamers and trolls appear to be a big problem, causing loss of trust in the system. Even if a closer look may find that behind many of the insults there is a peculiar kind of playfulness or may be "a marker of relationship closeness" (O'Sullivan and Flanagin 2003, p.73), not all are willing to accept such a way to interact, especially newcomers unaware of previous interaction dynamics.

The option of interfering with comments, even if to control monopolisation by rowdy presences, is easily perceived as an attack on free speech. Comment management options may affect pluralism and questions arise about the role of the moderator: a participant, an animator, or - as is often the case - a "policeman." Coleman and Blumler remind us of the importance of "sensitive skills of moderation," such as the ability to facilitate online discussions "in ways that enable the voices to be heard of citizens who do not necessarily feel bold, articulate or firmly committed to a particular point of view" (2009, p.174). Meaningful interaction may equally be hindered if European institutions limit their action to prompting debate, instead of engaging in it and replying to the contributions of citizens, like previous experience with discussion boards (Wright, 2006). Moreover, European political institutions find it difficult to avoid being perceived as manipulating public opinion, and escaping claims of producing citizenfunded propaganda. Such accusations have a long history and the fact is that EU 
Postprint version. Please refer to the published article for citation purposes:

Dias da Silva, Patricia (2013), "Joining the online video conversation? Discourse and practices of European political institutions and politicians on YouTube,” Int. J. of Electronic Governance, vol. 6 (4), pp. 281-301.

DOI: 10.1504/IJEG.2013.060644.

institutional communication serves political goals and has always done so. In the days of Jean Monet, "information was a way to enhance the political project (the creation of a political union between countries) that lay behind the first energy regulations" (Baisnée, 2007, p.498). Today, EU documents associate online communication policies with the fostering of the elusive European public sphere, instead of just discussing information dissemination.

Despite the EU's efforts in trying to adapt to digital media, particularly social media, they have to comply with a set of rules they do not define, in spaces they do not own. On the whole, the European Commission's plight in dealing with YouTube is very similar to that of European national political actors. As remarked by Strangelove, "[n]ew media practices typically change faster than institutionalized modes of representation" (2010, p.157). They have not been particularly creative in the content they upload, and features such as comments are not used in all their interactive potential: as has been observed about British political parties "[they] have jumped on the Web 2.0 bandwagon, but they are using the brakes and the reins to make their ride more comfortable" (Jackson and Lilleker 2009, p.248), with consequences to their acceptance by citizens. Formal videos are neither very successful in capturing the attention of the YouTube audience, nor in defining a favourable image of politicians. Although twenty-first century politicians try to control their image, "gotcha moments," parodies and all forms of exposure of politicians' faults have a wider circulation than sanctioned videos (Terblanche, 2011). Yet in considering that these forms of political expression do not enrich online discussion, the academic and political world may be ignoring humour's role in fostering political debate (Silva and Garcia, 2012).

Since scepticism concerning citizen participation has significant cultural roots, some transformations are still expected with time. According to Gabriel Tarde (1989 [1901]), speech (parole) was first used to utter monologues, well before conversations were had: "the dialogue only came after, in compliance with the law according to which the unilateral always precedes reciprocity" (1989 [1901], p.46). Perhaps online video will follow the same pattern. Otherwise, it will hardly help developing more deliberative models of democracy, fighting the European communication and democratic deficits, or changing negative perceptions regarding politicians and the European project. 
Postprint version. Please refer to the published article for citation purposes:

Dias da Silva, Patricia (2013), "Joining the online video conversation? Discourse and practices of European political institutions and politicians on YouTube," Int. J. of Electronic Governance, vol. 6 (4), pp. 281-301. DOI: 10.1504/IJEG.2013.060644.

\section{Sources:}

COM (1999) 687 final, eEurope. An Information Society for All, Communication on a Commission Initiative for the Special European Council of Lisbon, 23-24.3.2000

COM (2001) 428 final, European Governance. A White Paper, EC, Brussels, 25.7.2001

COM (2002) 263 final, eEurope 2005: An information society for all, EC, Brussels, 28.5.2002

COM (2004) 757 final, Challenges for the European Information Society beyond 2005, EC, Brussels, 19.11.2004

COM (2005) 229 final, i2010 - A European Information Society for growth and employment, EC, Brussels, 1.6.2005

COM (2006) 173 final, i2010 eGovernment Action Plan: Accelerating eGovernment in Europe for the Benefit of All, EC, Brussels, 25.04.2006

COM (2006) 35 final, White Paper on a European Communication Policy, EC, Brussels, 1.2.2006

COM (2007) 568 final, Communicating Europe in Partnership, EC, Brussels, 3.10.2007

SEC (2005) 985 final, Action Plan to Improve Communicating Europe by the Commission, EC, Brussels, 20.7.2005.

SEC (2007) 1742, Communicating about Europe via the Internet. Engaging the citizens, EC, Brussels, 21.12.2007

\section{Additional sources}

Commission of the European Communities and Council of the European Union (2000) eEurope 2002 - An Information Society For All. Action Plan prepared by the European Commission for the European Council in Feira, 19-20 June 2000, Brussels, 14.6.2000.

DG Communication (2009) Annual Activity Report. 1 January - 31 December 2009. European Parliament.

DG Environment (2009) EU Environment Policy Brief - April. European Commission.

European Commission (2005) Public Consultation on the new Information Society Strategy beyond 2005. Final Report, eEurope 2005.

European Commission (2007) 'EUtube reaches one million hits', Press release, October 15, at http://europa.eu/rapid/pressReleasesAction.do?reference=IP/07/1498\&format=HTML\&aged=1 \&language $=\mathrm{EN} \&$ guiLanguage $=\mathrm{en}$.

Reding, Viviane (2005) 'i2010: The European Commission's new programme to boost competitiveness in the ICT sector', Speech delivered at the Microsoft's Government Leaders Forum, Prague, 31 January 2005.

Wallström, Margot (2009) 'Prague in winter dress and the naked truth about EUTube', Margot Wallström's Blog, January 9, at http://blogs.ec.europa.eu/wallstrom/prague-in-winter-dress-andthe-naked-truth-about-eutube/. 
Postprint version. Please refer to the published article for citation purposes:

Dias da Silva, Patricia (2013), "Joining the online video conversation? Discourse and practices of European political institutions and politicians on YouTube,” Int. J. of Electronic Governance, vol. 6 (4), pp. 281-301. DOI: 10.1504/IJEG.2013.060644.

\section{References:}

Anderson, B. (1991 [1983]) Imagined Communities, Verso, London.

Baisnée, O. (2007) 'The European Public Sphere Does Not Exist (At Least It's Worth Wondering ... .)', European Journal of Communication, Vol. 22 No. 4, pp. 493-503.

Bakardjieva, M. (2005) Internet Society: The Internet in Everyday Life, Sage, London.

Barber, B. (1984) Strong Democracy: Participatory Politics for a New Age, University of California Press, Berkeley.

Brandenburg, H. (2006) 'Pathologies of the Virtual Public Sphere', in Oates, S. et al. (Eds.), The Internet and Politics: Citizens, Voters and Activists, Routledge, London, pp.207-222.

Burgess, J., and Green, J. (2009) YouTube: Online video and participatory culture, Polity Press, Cambridge MA.

Cardon, D. (2010) La démocratie Internet: Promesses et limites, Seuil, Paris.

Carpini, M., Cook, F.L. and Jacobs, L.R. (2004) 'Public deliberation, discursive participation, and citizen engagement: A review of the empirical literature', Annual Review of Political Science, Vol.7, pp.315-344.

Chadwick, A. and Howard, P.N. (Eds.) (2009) Routledge Handbook of Internet Politics, Routledge, New York.

Coleman, S. and Blumler, J. G. (2009) The Internet and Democratic Citizenship: Theory, Practice and Policy, Cambridge University Press, Cambridge.

Coleman, S. and Moss, G. (2008) 'Governing at a distance - politicians in the blogosphere', Information Polity, Vol.13 No.1-2, pp.7-20.

Correia, J.C. (2008) 'Novos Media e Esfera Pública: As profecias cyber-democráticas no contexto da Democracia Deliberativa', Estudos em Comunicação, No.4, pp.81-100.

Correia, J. C., Fidalgo, A. and Serra, J. P. (Eds.) (2003) Informação e Comunicação Online (VOL. III): Mundo Online da Vida e da Cidadania, LabCom Books, Covilhã.

Cunha, C. and Voerman, G. (2008) 'The Digitalization of the West European Party Systems', in Anttiroiko, A. (Ed.), Electronic Government: Concepts, Methodologies, Tools, and Applications, IGI Global, Hershey, PA.

Dahlberg, L. (2011) 'Re-constructing Digital Democracy: An outline of four "positions"', New Media \& Society, Vol.13 No.6, pp.855-872.

Dijk, J. (2012) The Network Society, Sage, London.

Dutton, W. and Peltu, M. (2007) 'Reconfiguring Government-Public Engagements: Enhancing the Comunicative Power of Citizens', OII, Forum Discussion Paper, No. 9 http://dx.doi.org/10.2139/ssrn.1295337 (Accessed 5 July 2013).

Eriksen, E.O. (2007) 'Conceptualising European Public Spheres. General, Segmented and Strong Publics', in Fossum, J.E. and Schlesinger, P. (Eds.), The European Union and the Public Sphere: a Communicative Space in the Making?, Routledge, New York, pp.23-43.

Fairclough, N. (1995) Critical discourse analysis: the critical study of language, Longman, Harlow.

Flichy, P. (2008) 'Internet et le débat démocratique', Réseaux, No.150 (4), pp.159-185. 
Postprint version. Please refer to the published article for citation purposes:

Dias da Silva, Patricia (2013), "Joining the online video conversation? Discourse and practices of European political institutions and politicians on YouTube,” Int. J. of Electronic Governance, vol. 6 (4), pp. 281-301.

DOI: 10.1504/IJEG.2013.060644.

Fouetillou, G. (2008) 'Le web et le Traité Constitutionnel Européen. Écologie d'une localité thématique compétitive', Réseaux, No.147 (1), pp.229-257.

Fuchs, C. (2009) 'Information and Communication Technologies and Society: A Contribution to the Critique of the Political Economy of the Internet', European Journal of Communication, Vol.24 No.1, pp.69-87.

Gagatek, W. (2010) The 2009 Elections to the European Parliament. Country Reports, European University Institute, Florence. http://cadmus.eui.eu/handle/1814/13757. (Accessed 5 July 2013).

Garcia, J.L. (2011) 'Internet, New Forms of Power and Democracy', Revista Internacional de Sociología, Vol.69 No.3, 756-759.

Gervais, J.-F. (2010) 'L'émergence de la vidéo sur le web: Facteurs et contextes', Documentaliste - Sciences de l'information, Vol.47, No.4, pp.30-3.

Gibson, R.K., Rommele, A. and Ward, S.J. (Eds.), (2004) Electronic Democracy: Political Organisations, Mobilisation and Participation Online, Routledge, London.

Golding, P. (2000) 'Forthcoming Features: Information and Communications Technologies and the Sociology of the Future', Sociology, Vol.34, No.1, pp.165-184.

Greffet, F. and Wojcik, S. (2008) 'Parler Politique en Ligne’, Réseaux, Vol.26 No.150, pp.1950 .

Gupta, A. (1992) 'The Song of the Nonaligned World: Transnational Identities and the Reinscription of Space in Late Capitalism', Cultural Anthropology, Vol.7 No.1, pp.63-79.

Habermas, J. (2009) Europe: The Faltering Project, Polity, Cambridge.

Hess, A. (2009) 'Resistance up in Smoke: Analyzing the Limitations of Deliberation on YouTube', Critical Studies in Media Communication, Vol.26 No.5, pp.411-434.

Hine, C. (2000) Virtual Ethnography, Sage, London.

Jackson, N.A. and Lilleker, D. (2009) 'Building an Architecture of Participation? Political Parties and Web 2.0 in Britain', Journal of Information Technology \& Politics, Vol.6 No.3, pp.232-250.

Jenkins, H. (2006) Convergence Culture: Where Old and New Media Collide, NYU Press, New York.

Lange, P. (2007a) 'Commenting on Comments: Investigating Responses to Antagonism on YouTube', Paper presented at the Annual Conference of the Society for Applied Anthropology. 31 March 2007. Tampa, Florida.

Lange, P. (2007b) 'Publicly Private and Privately Public: Social Networking on YouTube', Journal of Computer-Mediated Communication, Vol.13 No.1, pp.361-380.

Losh, E. (2008) 'Government YouTube. Bureaucracy, surveillance, and legalism in Statesanctioned online video channels', in Lovink, G. and Niederer, S. (Eds.), Video Vortex Reader: Responses to YouTube, Institute of Network Cultures, Amsterdam, pp.111-24.

Machin, D. \& Mayr, A. (2012), How to do Critical Discourse Analysis, Sage, London.

Mattelart, A. (2003) The Information Society: An Introduction, Sage, London.

May, A. L. (2010) 'Who Tube? How YouTube's News and Politics space is going mainstream', The International Journal of Press/Politics, Vol.15 No.4, pp.499-511. 
Postprint version. Please refer to the published article for citation purposes:

Dias da Silva, Patricia (2013), "Joining the online video conversation? Discourse and practices of European political institutions and politicians on YouTube,” Int. J. of Electronic Governance, vol. 6 (4), pp. 281-301. DOI: 10.1504/IJEG.2013.060644.

Millerand, F., Proulx, S. and Rueff, J. (Eds.), (2010) Web social. Mutation de la communication, Presses de l'Université du Québec, Quebec.

Mishne, G. and Glance. N. (2006) 'Leave a reply: An analysis of weblog comments'. Paper presented at the Third Annual Workshop on the Weblogging Ecosystem. 22-26 May 2006. Edinburgh, Scotland.

Monaco, J. (2000) How to Read a Film: The World of Movies, Media, Multimedia, Oxford University Press, Oxford.

O'Sullivan, P.B., and Flanagin, A.J. (2003) 'Reconceptualizing "flaming” and other problematic messages', New Media \& Society, Vol.5 No.1, pp.69-94.

OECD (2003) Promise and Problems of E-Democracy. Challenges of Online Citizen Engagement, OECD, Paris.

(2007) Participative Web and User-Created Content. Web 2.0, Wikis and Social Networking, OECD, Paris.

Proulx, S. (2008) 'Interroger la Métaphore d'une Société del'Information Horizon et limites d'une utopie', in Théorêt, Y. (Ed.), David contre Goliath. La convention sur la protection et la promotion de la diversité des expressions culturelles de l'UNESCO, Éditions HMH Hurtubise, Montréal, pp.99-124.

Proulx, S. and Jauréguiberry, F. (2003) Internet, Nouvel Espace Citoyen?, Editions L'Harmattan, Paris.

Rose, G. (2002) Visual Methodologies: an Introduction to the Interpretation of Visual Materials, Sage, London.

Sachdev, M. (2012), 'Harsh Reviews for European Commission Video Aimed at Closing Science Gender Gap', ScienceInsider, 22 June [online] http://news.sciencemag.org/scienceinsider/2012/06/harsh-reviews-for-european-commi.html (Accessed 5 July 2013).

Schlesinger, P. (2007) 'A Cosmopolitan Temptation', European Journal of Communication, Vol. 22 No. 4, pp. 413-426.

Silva, P.D., and Garcia, J.L. (2012) 'YouTubers as satirists: Humour and remix in online video', JeDEM - eJournal of eDemocracy and Open Government, Vol.4 No.1, pp.89-114.

Smith, N. (2007) 'Gasps All Round over the EU's Dirty Movie' The Times (UK), 1 July [online] http://www.timesonline.co.uk/tol/news/uk/article2010500.ece (Accessed 5 March 2009).

Strangelove, M. (2010) Watching YouTube: Extraordinary Videos by Ordinary People, University of Toronto Press, Toronto.

Swaan, A. (2007) 'The European Void. The Democratic Deficit as a Cultural Deficiency', in Fossum, J. E. and Schlesinger, P. (Eds.), The European Union and the Public Sphere: A Communicative Space in the Making?, Routledge, New York, pp. 135-153.

Tarde, G. (1989 [1901]) L'opinion et la foule, Presses Universitaires de France, Paris. http://classiques.uqac.ca/classiques/tarde_gabriel/opinion_et_la_foule/tarde_opinion_et_la_foul e.pdf. (Accessed 5 July 2013).

Terblanche, N. S. (2011) 'You cannot run or hide from social media—ask a politician', Journal of Public Affairs, Vol.11 No.3, pp.156-167.

UN. 2008. United Nations E-Government Survey 2008. From E-government to Connected 
Postprint version. Please refer to the published article for citation purposes:

Dias da Silva, Patricia (2013), "Joining the online video conversation? Discourse and practices of European political institutions and politicians on YouTube,” Int. J. of Electronic Governance, vol. 6 (4), pp. 281-301.

DOI: 10.1504/IJEG.2013.060644.

Governance, Department of Economic and Social Affairs, ST/ESA/PAD/SER.E/112.

Vieira, M.B. and Silva, F.C. (2013) 'Democracia Deliberativa Hoje. Desafios e Perspectivas', Revista Brasileira de Ciência Política, No 10 [online]

http://seer.bce.unb.br/index.php/rbcp/article/view/8615 (Accessed 2 July 2013).

Warburton, T. (1998) 'Cartoons and teachers: Mediated visual images as data', in Prosser, J. (Ed.), Image-based research: a sourcebook for qualitative researchers, Routledge, New York, 252-262.

Ward, S. and Gibson, R.K. (2009) 'European political organizations and the Internet:

Mobilization, participation, and change', in Chadwick, A. and Howard, P.N. (Eds.), Routledge Handbook of Internet Politics, Routledge, New York, pp.25-39.

Wesch, M. (2008) 'YouTube - An Anthropological Introduction to YouTube' Paper presented at Library of Congress, 23 June, Washington D.C, USA.

Wright, S. (2006) 'Design matters. The political efficacy of government-run discussion boards', Oates, S. et al. (Eds.), The Internet and Politics. Citizens, Voters and Activists, Routledge, London, pp. 80-99.

Wojcik, S. (2007) 'Les modérateurs des forums de discussion municipaux. Des intermédiaires démocratiques?', Questions de communication, No.12, pp.335-354.

Xenos, M.A. (2010) 'Guest Editor's Introduction', Journal of Information Technology \& Politics, Vol.7 No.2, Special Issue: YouTube and the 2008 Election Cycle in the United States, pp.89-92.

Yanoshevsky, G. (2009) 'L'usage des vidéoblogs dans l'élection présidentielle de 2007. Vers une image plurigérée des candidats', Mots. Les langages du politique, No.89, pp.57-68.

Zittel, T. (2004) 'Political communication and electronic democracy. American exceptionalism or global trend?', in Esser, F. and Pfetsch, B. (Eds.), Comparing Political Communication. Theories, Cases and Challenges, Cambridge University Press, Cambridge, pp.231-250. 